\title{
Constitutional Change in Switzerland
}

\author{
Dietmar Braun*
}

The article presents a case of successful constitutional change in Switzerland, the "re-assignment of responsibilities between the federal government and the cantons and the new fiscal equalization scheme," which was adopted in 2004 by referendum. By starting from the general assumption that ways and means are needed to strengthen general interests at the expense of distributive interests in constitutional discussions, the article endeavors to identify favorable conditions for successful constitutional change. By using insights from "constitutional political economy" and "actor-centered institutionalism," four such conditions are revealed: the procedural separation of problem solving and bargaining interaction modes; the importance of ideational factors like "frames," "causal theories," and focal points; active agenda-crafting; and the structuring of constitutional debates by earlier decisions. In addition, this article highlights that other conditions, more directly linked to interest and interest struggle, can help to mitigate the intensity of distributive conflicts and are therefore indirectly conducive to a problem-solving interaction orientation of actors.

\section{The Object of the Study}

In November 2004, the Swiss people accepted a new equalization scheme and a fundamental revision of competences-the so-called "new equalization scheme" ("Neuer Finanzausgleich"; NFA) between the federal government and the "cantons," that is the member states, with sixty four percent voting Yes and refusal by only three of twenty six cantons. ${ }^{1}$ This enacted twenty seven changes in constitutional articles and more than thirty modifications of laws. Two years later, an implementation law ${ }^{2}$ was enacted, and, in 2007, the federal parliament adopted the precise procedures to follow in implementing the equalization scheme. In both cases, no referendum was demanded, though this would have been possible under the Swiss constitution. The new federal order has been valid since January 1, 2008.

*Universite de Lausanne, Switzerland; Dietmar.Braun $@$ unil.ch 
The new system means a profound change in philosophy and practice, in respect both to the organization and to the financing of the federal order (for a more detailed overview, see Rey 1994; Dafflon 2004; Braun 2007):

- A far-going disentanglement of tasks.

- In those task areas that continue to be organized in a cooperative fashion, the competence distribution is now designed along the lines of new public management and principal-agent theory.

- An intensified collaboration between cantons; in case of conflicts between cantons, the confederation can enforce collaboration.

- Subsidies of the confederation for the revenue and the cost equalization scheme are no longer possible; instead of the former "vertical equalization scheme," where the federal government took care of equalization alone, a "horizontal equalization scheme" which obliges cantons to share resources between them, is introduced. The confederation is still participating, though. The objective is that each canton should have, at a minimum, eighty five percent of the average revenue of cantons.

- A new index, the "tax potential index," is introduced to calculate the legitimate claims of cantons for equalization.

- The new cost equalization scheme does take-and this is new-unfavorable socio demographic features of certain cantons into account. This concerns, above all, cantons with large cities. Cantons with large mountainous regions are also entitled to receive money out of this scheme.

- Finally, a "cohesion fund" is introduced during a transition period in order to soften the financial consequences of the new equalization scheme for some cantons.

One can speak of a profound change because the federal government had obtained more and more competences and, by way of grants, codetermination rights in many task areas during the 1960s and 1970s, which were originally attributed to the cantons. The disentanglement was conceived as a constitutional measure against the "creeping centralization." Collaboration between cantons did exist before in the form of special treaties (so-called "concordats"). What changed is the obligation to collaborate in the stipulated task areas. The cantons are not free anymore to participate or not in such collaboration. The new organization of concurrent task areas on the base of new public management considerations replaces the existing non-transparent, non-institutionalized, and ad hoc organized cooperation between the federal government and the cantons, which had blurred responsibilities and led to irresponsible expenditure behavior. Furthermore, the new tax potential index is supposed to reduce incentives for manipulating taxes and expenditures at the cantonal level. The reference to an equalization objective of eighty five percent, which did not exist before, must give a minimal guarantee of 
protecting the basic needs of cantons without leading to "rent seeking." The combined horizontal and vertical equalization scheme is designed in such a way that all cantons should have sufficient means in order to fulfill their assigned tasks without being dependent on further influx of federal money. This satisfies the objective of "fiscal equivalence" or "connectivity" between revenues and expenditures (Olson 1969). The "cohesion funds" now include the demands by the so-called center cantons (with large cities), which suffered chronically from the burden of their unfavorable socio-demographic structure. Finally, the separation of cost and revenue equalization, which were mixed up before in the grant payments by the federal government, is supposed to prevent further inefficiencies in equalization.

Our objective in this article is to explain how such a fundamental constitutional change, which demanded a profound redistribution of "property rights" and financial flows, became possible in Switzerland while other countries like Germany and Austria, which were also striving for encompassing federal reforms, had to be content with quite modest results or with failure. ${ }^{3}$

Those who are familiar with the Swiss political system, with its typical features of "consociational democracy" and the "functional entanglement of territorial levels" (Linder 1994) would guess that such a profound change is in principle very unlikely. The inclusive Swiss political system gives a large number of "veto-players" numerous veto-points (Immergut 1992) to intervene; ${ }^{4}$ however, according to vetoplayer theory (Tsebelis 2002, 24-25), increasing numbers of veto-players reduce the "win-set" and therefore the possibility of overcoming the status quo.

In order to find plausible explanations for this successful reform, we believe that assumptions of pure "opportunism" underlying rational choice theory in general and veto-player theory in particular are insufficient to explain constitutional change. A number of additional theoretical insights are needed from the constitutional political economy literature (Buchanan and Tullock 1962; Jillson and Eubanks 1984; Brennan and Buchanan 1985; Vanberg and Buchanan 1989) and from "actor-centered institutionalism" (Scharpf 1997). These insights are elaborated in the next section. On the basis of these insights, we develop a number of conjectures suggesting possible causal mechanisms that help to make successful constitutional change understandable. The reform process is then described and analyzed.

The intention of this study is to suggest on the basis of this exploratory case study possible causal mechanisms for successful constitutional change that can contribute to concept development in future comparative research.

\section{Theoretical Considerations and Conjectures}

The main problem of constitutional consensus building is overcoming selfish or "material" interests of participating actors. Material interests are always present if 
the political issues under discussion touch upon the redistribution of authority and resources among actors. As long as these issues are not subject to a zero-sum game or to a competitive or hostile "interaction orientation" (see Scharpf 1997, 84-89), bargaining can, of course, solve distributional issues. But in most cases such "negotiated solutions will reproduce the existing distribution of advantages and disadvantages" (123). With a large number of veto-players and distributive bargaining, it will be difficult therefore to overcome the status quo if "redistributive issues" and general concepts of "distributive justice" are involved (123). Constitutional discussions that deal with these questions need a "problemsolving" frame, a state-of-mind of actors that "focuses on value creation," on "better projects or objects" (130). In other words, an interest of actors in "welfare-superior solutions" is needed, and not strategies of maximizing individual benefits.

The main question is, how is such a state of mind achieved? The answer to this question should help to explain how such an encompassing redistributive agreement, reforming the federal order, has been possible in Switzerland. We try to highlight three dimensions that seem pertinent to the erection of a "problemsolving" interaction mode: procedural separation of problem-solving and bargaining, the working of ideational factors, and mechanisms linked to the reform process as such.

\section{Procedural Separation of Problem-Solving and Bargaining as a Necessary Condition}

The first point concerns the character of constitution building as a negotiation arena. Authors in the tradition of "constitutional political economy" contend that building consensus on constitutional issues follows a different logic than pure distributive bargaining. Distributional issues certainly cannot be eliminated from discussions of constitutional issues, but they may be more in the background or have no prominent role at all. Why is that?

The main argument is that constitutional issues are different from pure distributional issues, because they must deal with general principles and rules concerning the organization of the polity and general norms that are to be respected. More precisely, such principles are property and implementation rights, decisionmaking and distribution rules, as well as procedural ways and means that structure the struggle for the distribution of rights and resources. Usually, these principles are of a fundamental nature and are conceived as long-term settlements. Constitutional principles and rules should not, like simple law measures that might be revised with every change in government, for example, be subject to constant revision. 
It is this long time-horizon of constitutional rules that has led to a more positive judgment about the possibilities of coming to an agreement among opportunistic actors negotiating constitutional issues. Two arguments are offered:

The first argument (see Vanberg and Buchanan 1989) highlights the character of a mixed-motive game that seems typical for constitutional issues and makes it difficult for actors to defend their cause principally by referring to their distributive interests: Each actor has an interest in stable frameworks of action in the future, as only such stable frameworks guarantee that the political game can be played and pay-offs can be realized. The stability of the framework as such is therefore useful for actors. Principles and rules are there to develop such a stable framework. This is why constitutional issues cannot be discussed simply in terms of selfish material interests. "Arguing," Elster writes, that is the rational discussion about general rules, is next to or replaces "bargaining" $(1986,1991,4) .^{5}$ Actors have a common interest in developing and defending such a stable framework. As a consequence, constitutional arenas are different from pure distributive arenas because it becomes easier for actors to refer to the common good, or it is imperative also to refer to the common good.

The second argument refers to the uncertainty that exists in constitutional discussions because of the long time-horizon. The nature of principles is that they are conceived to be valid for a large number of situations or cases, and for an unspecified time. The basic argument is that both the generality of principles and the long-term perspective make it difficult for actors to estimate eventual consequences of these principles for their future position in politics and society. They must decide behind a "veil of ignorance" (Rawls 1999). This has led Rawls to assume the well-known "difference principle" according to which the position of the "worst-off" groups in society will be ameliorated while Buchanan (1987) states that it allows to more easily make abstractions of personal interests and impartially judge the advantages and disadvantages of such rules or principles for the community. ${ }^{6}$ Uncertainty favors impartial judgments and is therefore conducive to developing a "problem-solving" frame and overcoming a pure distributive orientation.

All this explains why predictions derived from veto-player theory will be less reliable in discussion of constitutional questions. "Psychological conditions" (Scharpf 1997) are different in the constitutional arena; however, there is no guarantee nor is it probable that the "distributive frame" is excluded from constitutional discussions. A "mixed motive game" does not discard distributive orientation, and the "veil of ignorance" may be too thin to hide distributive consequences of constitutional issues. The main issue therefore remains how a "problem-solving" frame, which becomes a real possibility in the context of constitutional decisions, can be achieved, or, in the terminology of constitutional 
political economy, how the "veil of ignorance" can be "thickened" (see Vanberg and Buchanan 1989). In order to do so, Scharpf contends, a procedural separation of distributional and problem-solving questions is needed (Scharpf 1997, 135; see also Scharpf 1988 and Zintl 1992).

We conjecture that such a procedural separation is a "necessary condition" for the establishment of a problem-solving interaction orientation in the context of such far-reaching and redistributive reform as the NFA has been in Switzerland. We do not, however, consider this condition sufficient; one can hypothesize that other facilitating factors might also be needed. Ideational factors for example are "substitutable" in the sense of Goertz and Mahoney (2005), that is one or more of these factors may be present and facilitate problem-solving, but they are not a necessary condition.

\section{Ideational Factors}

Ideational factors are often discounted in the rational choice tradition, though it seems obvious that they may have an influence on the orientation and preferences of actors (Braun and Busch 1999; Schmidt 2008). Vanberg and Buchanan (1989, 51) point out that the choice of actors is "not only a matter of 'what he wants' but also 'what he believes." " Belief or "theories" are considered to be most important for constitutional choice, that is, "for choice among rules." The main point is that actors need shared belief systems that can serve as a medium to overcome egoistic, distributive orientation. The literature offers three notions that go in this direction: focal points, frames, and causal theory.

\section{Focal Points}

One of the main obstacles to a shift in interaction orientation is the fear of actors of becoming the victim of transgressions by other actors or that actors will not keep their promises after an agreement has been reached. The rational answer to such fears is non-solidaristic, opportunistic behavior, which in turn does not allow for problem solving. One way to avoid this trap is mentioned by Garrett and Weingast (1993): if actors can agree on a "focal point" (Schelling 1978), they may be able not only to develop sustainable cooperation but also to reach an agreement that is credible to all actors. A focal point serves to avoid ambiguities in interpretation of agreements once they have been reached and therefore helps to sanction defection. A focal point can be a notion like "sovereignty," as Weingast (1995) demonstrates in the case of the peace of Westphalia, or "subsidiarity" in the case of the European Union. This is our hypothesis: if negotiating actors are able to agree upon such a focal point, they can enhance the willingness of actors to enter the discussion about "risky" agreements. 


\section{Frames}

A second ideational notion is the "frame" used by a group of actors to interpret arguments, propositions, or events (Tversky and Kahnemann 1974; Lindenberg 2000). The general idea behind this concept is that there are different ways of "selecting, organizing, interpreting, and making sense" (Rein and Schön 1993, 146). A frame establishes a coherent way of interpreting the world, and this concept applies also to problems and solutions in policy making or constitution building. As multiple frames are possible, this may lead to considerable tension between political contenders (Rein and Schön 1993, 147-148). On the other hand-and this is the important point in this context-frames also allow conflicting interests to be overcome: if actors succeed in sharing the same frame, and this frame focuses, for example, on the production of common goods instead of on maximizing gains or minimizing losses, the chance that an agreement will be reached increases. If, therefore, a frame can be established that strengthens an orientation toward the common good, a problem-solving attitude can be promoted.

\section{Causal Theory}

In a similar way, one can conjecture that shared causal stories, or in our context shared constitutional theories, that is "theories about the working properties of alternative rules and rule-systems" (Vanberg and Buchanan 1989, 51) can be conducive to problem orientation. Such theories specify causal relations, that is beliefs about the effects of certain political measures and instruments. If divergent causal theories about one and the same phenomenon exist-as for example a Keynesian and monetarist explanation of the causes of unemployment-this may contribute to political struggle. If, however, only one causal theory gains currency, it becomes easier to arrive at similar conclusions about consequences of certain measures. This contributes to "arguing" in political discussions. Once adopted, such causal theories work like a frame. We can therefore state that if there is only one single causal or constitutional theory on effects of political measures, it becomes easier to achieve a problem-solving attitude of actors.

\section{Process Factors}

Two process factors seem relevant in our context, one as a necessary component (agenda-crafting), the other as a facilitating condition (time):

(i) Riker (1984) pointed to the necessity of working on a "dynamic theory of constitution making" and called for overcoming the "static character" of rational choice theory. During the process of constitution making, actors have the possibility of inventing, revising, and eliminating alternatives. The important point he made is that this process can be "manipulated." The separation of arguing and bargaining must and can be actively achieved by agenda-crafting. Then, alternatives that appear at the beginning of the process 
may disappear and be replaced by others. There is a constant construction and deconstruction of alternatives. Skilful agenda-crafting can, therefore, be not only a facilitating factor for the achievement of problem solving but also even a necessary one. It is difficult to see, for example, how procedural separation of "arguing" and "bargaining" can be achieved without manipulation of the process. Agenda-crafting must precede procedural separation.

(ii) A second process element to be mentioned is time and its effects. Although there may be different influences, we want to point out only one: constitution building is usually not an affair of a couple of weeks. As it concerns fundamental questions and generally needs oversized majorities in parliament or even a confirmation by a referendum, as is the case in Switzerland, the time-span of constitutional debates is usually quite long and proceeds in stages (preparatory committees, discussions in general forums, decisions on first proposals, amendments, etc.). This "chain" of constitution making lends itself to the structuring of debates: decisions or agreements in one stage have an influence on decisions or agreements in later stages. Decisions that are made constrain future options and choices, making the manipulation of the beginning phase in constitutional debates very important. If one succeeds in "arguing" during this initial stage, the chances of maintaining "problemsolving" throughout the process increase.

Concerning the influence of process variables on problem-solving, one can therefore assume that, first, agenda-crafting of the process is an indispensable element for success and, second, that long-lasting constitution-making processes can be conducive if agenda setters succeed in manipulating the initial stage of constitutional debates in favor of a problem-solving interaction orientation.

In sum, there are plausible conjectures based on constitutional political economy and actor-centered institutionalism that can help explain the apparent unlikely case of an encompassing, redistributive constitutional reform under conditions of a strong inclusion of multiple veto-players, as in Switzerland. Constitution makingin contrast to "normal" policy making - is by definition a mixed motive game and therefore allows in principle the establishment of "problem-solving" and "arguing" as the dominant interaction mode between actors instead of bargaining. The procedural separation of bargaining and problem solving and agenda-crafting can be seen as necessary conditions to do so, though they cannot be considered sufficient conditions. Ideational factors and the long-standing character of constitution making may, as facilitating and substitutable factors, support the promotion of problem solving.

The following section will analyze to what extent these conditions have indeed played a role in the reform of the federal order in Switzerland. 


\section{The Constitution-Making Process}

Constitution making in Switzerland is embedded in a particularly strong case of a "consensus democracy," which is, according to Lijphart, polar opposite to majoritarian cases like New Zealand and the United Kingdom (Lijphart 1999). There are several explanations for the origins of Swiss consensus democracy. A prominent one is given by Neidhart (2002) who points to the effects of direct democracy established in Switzerland: as direct democracy establishes a system with many potential veto-players, it becomes primordial for political actors to find an encompassing consensus during the political decision-making process. The integration of potential veto-players during this process reduces the probability of contestation in the ratification process and, if there is contestation, raises the chances that the legislative proposal will be accepted by a majority both in the population and in the cantons. As all changes of the constitution need a referendum, early consensus building is therefore a conditio sine qua non for success (Linder et al. 2008).

In constitution building such integration takes for example place in extensive pre-parliamentary procedures (Sciarini 2004): A pre-consultation of stakeholders (interest groups; cantons) may take place to test the potential support, the applicability, and the validity of a proposal presented by the federal administration. In addition, all constitutional amendments need a formal consultation (the so-called "Vernehmlassung") giving stakeholders the opportunity to react by written comments on the proposal of the federal government. Only after these two stages, the "message" of the federal government, that is the legislative proposal or constitutional article is presented to the parliament.

If one makes abstraction of the time these procedures need, constitutional change is comparatively easy in Switzerland and often happens: constitutional amendments may come from the federal government, the cantons and the parliament on one hand and interest groups on the other if they can present a certain number of signatures of citizens. In order to change the constitution, it needs a simple majority of the two chambers, which of course must be confirmed by a referendum.

The reform of the federal order we are dealing with in this article started in 1972, when parliamentary representatives demanded a reform of the existing competence distribution between the federal government and cantons in favor of more decentralization. ${ }^{7}$ This initiated a longer process of negotiations that finally resulted in several modifications of the constitution at the end of the 1980s. However, this reform can be considered more or less a failure, as the agreed-upon revision of the competences between the federal government and the cantons cannot be considered substantial and did not satisfy neither the cantons nor the federal government (Freiburghaus 2001). The demand for a re-assignment 
of federal competences had therefore already been on the constitutional agenda before the NFA process started and continued to play a role in the minds of actors.

The NFA reform discussion started immediately after adoption of the first reform, which is a strong evidence of general discontent about the previous reform. The initiative was taken by the Conference of (Cantonal) Finance Ministers (Konferenz der Finanzdirektoren; CFM), which demanded that the federal government deliver an impact analysis of ongoing subsidy and equalization practices of the federal government. The federal finance department published the report in 1991. The report was the basis of a "framework program" of reform (Orientierungsrahmen) the CFM published in 1992 (Conférence des directeurs cantonaux des finances 1992). The federal government together with the CFM decided in 1994 to consult with four economic experts with the mandate to present solutions to the problems raised in the framework program. Equipped with the expert report (Frey et al. 1994) and the framework program, a "project group," composed of representatives from the federal and cantonal finance administration and equipped with a coordinating secretariat, was asked to prepare a legislative proposal for the federal government. The proposal was delivered in 1996 (Département Fédéral des Finances 1996) and sent in the usual pre-parliamentary procedure, the Vernehmlassung, to actors concerned, especially to cantonal actors. Actors can give a written statement, which the federal administration is formally free to take into account. After gathering statements, the federal government decided to launch the preparation of a full legislative proposal. Such a two-step process is relatively unusual in the Swiss reform process. It was decided to enlarge the project group by integrating members of other federal departments, possible stakeholders, and scientific experts. The objective was to discuss the problems that had been raised in the hearing procedure, find solutions, and prepare a proposal that could again be sent to a second pre-parliamentary hearing. Deliberations lasted three years. A scientific report published in 2001 elaborated likely financial consequences of the agreement-a demand of a number of cantons (Larpin 2006, 71; Frey 2001). The organization of the cantons, Conference of Cantonal Governments (CCG; Konferenz der Kantonsregierungen), approved the final report of the project group in the same year, with a majority of twenty four for and two against. The "message," the legislative proposal of the federal government, was sent to Parliament in the same year (Conseil Fédéral 2001). Parliamentary proceedings started in October 2002 and lasted one year. Votes in both chambers were largely in favor of the legislative proposal [thirty eight for and two against in the Council of the States (Ständerat) and 121 for and fifty four against in the National Council (Nationalrat)]. The constitutional amendments were accepted by the people on November 28, 2004. 
Procedural separation of distributive bargaining and problem solving, or "arguing," is seen, as outlined earlier, as a necessary factor of success. Did it occur in the case of the NFA?

In the beginning, the project of the NFA contained two different reforms: one was directed at federal competences, the other at fiscal equalization. Reform occurred before the NFA had dealt with the distribution of competences between cantons and the federal government but not with questions of revenue redistribution. The NFA reform started by attacking fiscal equalization specifically, and only later, in 1994, were both reform strands brought together. Both reforms were sensible for distributive conflicts; "who should get what" in matters of competences and "how much" in fiscal equalization were the main questions. But in both reform strands, general questions, principles of how to distribute on the basis of what rationale with what intention, had to be discussed first. Such discussions took place first within the finance administration, then in the expert group and the first project group. It was clear that, once a proposal was presented to concerned actors, this general level of discussion could be lost and more specific distributive interests would enter the discussion, making an agreement on these sensitive topics very difficult.

The solution was a "phasing" of the reform in two steps, first a discussion on general principles of the reform as discussed by the project group, and only later a proposal that would reveal the more concrete consequences of the principles adopted. To this end, the federal government decided at the time of the first pre-parliamentary hearing not to bring in an airtight proposition that would already entail all essential elements of the final legislative proposal and reveal the consequences, but to present a tentative proposal containing only the general principles of a future reform. Except for the fact that this prevented "down to earth" distributive discussions, this decision also intended to induce the cantons to state their fundamental opposing arguments against the reform so they could then be integrated into the discussions of the second project group, which had to prepare the final legislative proposal. In doing so-and this was a result of "agenda-crafting"- - kind of "veil of ignorance" was established, because actors, in this case, the cantons, most likely would guess possible outcomes of the new principles, but they could not know for certain or in any detail. This facilitated discussions of general principles (Larpin 2006).

The first pre-parliamentary hearing could therefore maintain a very general and "problem-solving" level of discussion, and the gathering of different opinions helped to prepare the discussions in the second project group and to prepare a general consensus on the basic principles of the project.

In fact, it appears that transparency about the specific financial consequences was lacking until the very end of the project. Proof of this is the urgent demand by 
a number of cantons as late as 1999 to deliver a study of the financial consequences, which became the second export report published in 2001, when the CCG had already approved the overall project. Nevertheless, one can assume that the "thinning" of the "veil of ignorance" began to start with the debates in the second project group in 1997, when questions about distributive consequences became more and more salient. One of the main tasks, according to Wettstein (2002), the secretary of the project group reports, was therefore to keep the main principles alive in the discussion. The more topics pertinent to distribution appeared on the agenda, the more ways had to be found to refer to the general agreed-upon principles and rules. This link could not be broken if one wanted to succeed during distributive discussions.

So, by careful "agenda-crafting" a procedural separation of "arguing" and "bargaining"indeed took place. Commentary by the secretary of the reform project leaves no doubt that this separation played a most conducive role in acceptance of the overall project (Wettstein 1998, 2002; Siegenthaler and Wettstein 2004).

\section{Ideational Factors}

We believe we can identify all three types of "shared beliefs" in the reform process and point out their facilitating effect for consensus building in the constitutional arena, shared frame, focal point, and causal theory.

\section{Frame}

When the "framework program" of the CFM was published in 1991, it was full of "new public management" thinking: reforms should be prepared in order to use resources more efficiently; clear objectives, purposeful steering, and transparency of procedure should be central. A closer look into the framework program reveals that, at the beginning of the 1990s, "efficiency," that is cost-effective action, became the main "frame of reference" in the reorganization of the federal and cantonal states. This is confirmed by a number of studies (Rieder and Lehmann 2002; Blindenbacher et al. 2004). Major reforms, above all the reform of the federal administration in 1997, were inspired by new public management thinking. The reform of the NFA was no exception. It became almost impossible to reform the organization of the state, including intergovernmental relations, without pointing to or legitimizing this reform by a reference to the notion of efficiency or use of basic ideas from new public management philosophy. ${ }^{8}$ In this sense, then, it became a "frame," an interpretational framework that was used extensively to judge the proposals made in the context of the NFA.

This frame had the advantage of both creating a sense of collective action and appeasing distributive demands: if efficiency became the general frame of interpretation, used in the diagnosis of and search for solutions to federal 
problems, actors were obliged to justify their individual interests in terms of a common good: efficiency explicitly refers to the functionality of the system and not to particular interests. In addition, efficiency promises more effective political action with less cost to invest. Efficiency gains can therefore benefit all sides. The federal government could generously promise that all cantons would in the end have enough money to fulfill their tasks, because the theory predicted increased revenues as a result of more efficient use of expenditures. The federal government could also do more with fewer resources, which was an important argument in the context of a serious budget crisis of the federal state. Efficiency was therefore a sword with two sharp edges: the notion could help to remind actors time and again of the importance of the common good and it promised distributional advantages for all participants.

As efficiency arguments were used throughout the constitutional debates, they can be seen as important in transforming discussions from the mode of "bargaining" into that of arguing.

\section{Focal Point}

In our opinion, the notion of subsidiarity played the role of a "focal point," as outlined earlier. In addition to the objective to provide cantons with sufficient revenues in the future to fulfill their tasks, subsidiarity has explicitly been formulated as a norm to be respected during the proceedings of the first "project group," and it has remained an important key notion throughout the whole reform period. It was also used in debates on the general revision of the constitution that were finally concluded in 1999. It is explicitly mentioned in Article 47 of the revised constitution that the federal government has to respect the autonomy of cantons and also that the principle of subsidiarity should reign in federal relations with cantons.

Subsidiarity can be seen as a focal point, because it was instrumental in concluding compromises during constitutional negotiations by protecting the domains of interests of both cantons and the federal government: The cantons had the promise of the federal government to abstain from "predatory behavior" and the federal government kept the right to fulfill its tasks defined in the constitution. What is more, the notion helped to determine at a later stage, which tasks should be assigned to which territorial level (Gygi 1999, 41). It was therefore not only a focal point but also a general principle for distributing competences. This facilitated the coordination of actors.

\section{Causal Theory}

The frame of efficiency was useful, but it could not work without a "causal theory," that is without convincingly demonstrating that the acceptance of efficiency would indeed result in mutual gains for actors. Economists delivered this theory. 
New public management was the main causal theory behind the notion of efficiency, but it was not difficult to also link the economic theory of fiscal federalism to efficiency (Tiebout 1956; Olson 1969; Oates 1972). This is not astonishing as both theories are offspring of public choice theory. The economic theory of fiscal federalism had the advantage, compared to new public management, which is more directed to "governance" in general, of having a coherent causal theory of fiscal equalization at its disposal. This became important in the context of the NFA reform, because once the guidelines of the CFM had been published, several economists were mandated by the federal government to map out how a more efficient fiscal equalization system could definitely be achieved. The economists were close to each other in their theoretical orientations. They were able to deliver such a model with clear guidelines for action promising advantages for everybody (Frey et al. 1994).

The expert group, however, did more in relation to the "framing" of the overall discussion. It added one important element, that is the linking of the reform of fiscal equalization and the re-assignment of federal competences, which had been on the agenda before. By applying an economic theory of fiscal federalism, the scientists endeavored to demonstrate that an efficient fiscal order cannot be achieved without a reconstruction of the whole federal order, and this also clearly meant a re-assignment of competences. The existing fiscal order was inefficient, experts maintained, because it had led to "excessive centralization" (Frey et al. 1994), while economic theory had always underlined the advantages of a decentralized federal order. The economists supported the principle of "connectivity" and "fiscal equivalence" (Olson 1969), which should strengthen the fiscal capacity of cantons and introduce a clear and transparent separation of competences between the federal and cantonal level. Federal grants were considered too detailed, too complex, and without sufficient control of their use by cantons. From these observations, which were of course much more elaborated, the experts determined clear guidelines to optimize the existing competence assignment, to establish a horizontal fiscal equalization scheme, and to strengthen fiscal capacities of cantons in general.

By doing this, experts established a nexus between the two previously separated reform topics, equalization and competence assignment, and this nexus remained valid throughout the reform process. The important contribution was that both reform topics were from now on discussed in terms of one "constitutional theory," one causal narrative. A reform of fiscal relations had become a reform of the federal order in general. The use of one causal theory strengthened the cohesiveness of the reform project considerably. The frame of thinking of economic experts was accepted by the first project group and guided further propositions.

The straightforward acceptance of the proposals, the acceptance of the economic "causal story," was favored by the composition of the first project group, which 
was composed of representatives from the federal financial department and from the cantonal finance administration, selected by the CCG (Larpin 2006, 55; Wettstein 2002). It was, of course, not by chance that four economists were selected for the task. The financial administration almost naturally addressed economists whose thinking was close to their own. The discussion was, moreover, at the beginning quite technical and focused on equalization questions, though it became increasingly clear that a complete system change had to take place. During this initial phase, one can almost speak of a "discourse subsystem" that was relatively closed and decoupled from other reform areas (Freiburghaus 2001, 17). By keeping the discussion confined within a "discourse subsystem," an "epistemic community" (Haas 1992) of political and scientific financial experts could come into existence. This was-in unison with the low degree of politicizationfunctional for a "rational" discussion on the topic as well as for the emergence of a relatively unified "frame" that could influence the reform discussion until the end. This also had the effect that the whole topic of fiscal equalization remained relatively depoliticized. Only after the first hearing had taken place did other ministries participate in constitutional discussions.

One cannot underestimate the importance of this "framing" process. The acceptance of a relatively coherent causal theory granting coherence to a multilevel and complex reform project structured further discussions by constituting a frame in itself. Any opposition to such a powerful frame needed a convincing alternative causal theory, which, given the technical character of the project and its complexity, was difficult to establish.

\section{Process Variables}

The description of the development of frames and causal theory helps to underline one important further conclusion that seems to have mattered and which lends itself to skilful "agenda-crafting": the structuring of constitutional debates. The development of a unifying causal theory and frame within the close-knit epistemic community of the financial administration was crucial for future discussions, as indicated above. Given the complexity and technicality of subjects, an existing frame had the effect of a constant point of reference that actors needed to address by "arguing" within the constitutional arena. The frame of efficiency induced a "systemic orientation" in discussions and favored a problem-solving attitude. The economic theory of federalism presented clear-cut and understandable solutions. Any opposition needed a substantial opposing causal theory to restructure the reform, and such an opposing theory was not available. This did not exclude opposition to various issues, most notably to possible negative consequences of welfare payments by the Socialist Party, but the overall thrust and direction of the reform was never attacked, once the first proposal was presented in 1996. 
As indicated, "manipulation" was needed time and again by the coordination committee to maintain a link to the underlying frame and causal theory when distributive questions were on the agenda of discussions, but an alternative was not discussed.

This structuring effect can also be found when, later, Parliament had to discuss the legislative proposal. The reform was clearly a project of the finance administration. It then became broader but remained a project that was overwhelmingly determined by discussions and negotiations between members of the executive. The important role of the CCG in the handling of reform discussions confirms this. Governments of course had to look for majorities in parliaments, but the preparation and handling of the project as well as problem-raising and solutionfinding had been in the hands of the federal and cantonal administration. This facilitated a focus on the feasibility of the project and on efficiency aspects while party ideology was put in the background. But more important here is the fact that it was very difficult for Parliament to oppose the legislative project, because it had been a long and difficult process to reach a compromise within the project group. There were of course discussions of particular questions, but the parliamentary discussion on the NFA proceeded very quickly and without major conflicts. Majorities in both chambers were reached with no problems within one year. This relative ease of acceptance confirms the dependence of parliamentary discussions and decisions on preceding processes: a complex reform project pre-negotiated by numerous actors and above all by territorial powers and presented after long years of preparation puts considerable pressure on the Parliament to accept such a proposition. It certainly lacked alternatives that could have been used to put the reform into question. Most parties supported the project without criticism. Only the Socialist Party, together with the association of handicapped people and trade unions, opposed the project, because it believed that the transfer of competences for social policy to the cantons-which was projected in the legislative proposal-would have negative effects on their welfare clientele. This was a serious point of criticism, because it could find support among the people, but it was not an alternative to the project. This reduced the chances of its success as even among the people the opinion prevailed that a reform was needed, and one could not reject the whole project on this argument (Larpin 2006).

\section{Agenda Crafting}

There is evidence that "agenda-crafting" has played an important role in the development of the reform project (see above all Wettstein 1998, 2002). A number of points can be summarized as follows:

- In 1994, the financial administration deliberately contacted economists whose thinking was close to that of the financial administration. 
Experts from other social science disciplines played no role during the reform process.

- The integration of scientific experts into the various subcommittees of the second project group, and later in the form of mandates, was, as already indicated, a medium to remind stakeholders of the overall frame and to maintain a problem-solving dimension in the discussion.

- Maintenance of the coherence of the project was a continuous preoccupation of the coordinating committee and was achieved not only by use of experts but also by agenda manipulation, the choice of committee presidents, and other means.

- The decision to divide the preparatory phase of the legislative proposal into two phases strengthened the problem-solving dimension.

- The decision to establish a smaller first project group in 1994, composed of financial administration officers, helped to develop the unified frame and causal theory.

- The decision of the federal government to include representatives of cantonsfirst representatives nominated by the CFM and then by the CCG-in a more than formal way. This helped substantially to create goodwill among cantons. Although it was clear that cantons must have a "voice" in the preparation of a federal legislative proposal on the federal order, the inclusion went much farther: in fact, the cantons played the role of an equal partner in constitution building on the federal level and had equal rights in decision-making and prominent positions in the development of the project. The legislative proposal became in fact a "joint proposal" of the federal government and the CCG, representing the cantonal governments, and was written together.

- An intensive media campaign was set up after the legislative proposal was sent to Parliament (Larpin 2006). This campaign was important to raise awareness among the people before the referendum to the difficult and complex topic that had to be decided.

- In order to overcome the resistance of the Socialist Party, members of the coordinating committee tried to convince cantonal representatives of the Socialist Party of the advantages of the overall project. This helped to split party opinion during the parliamentary votes and the referendum.

These points suggest an active handling of difficulties occurring during the reform process and a prudent and proactive intervention on many occasions. Agenda-crafting was without doubt the basis of the procedural separation of "arguing" and "bargaining." One cannot assess exactly the degree to which "agenda-crafting" has been a decisive element, but the various decisions made in order to organize the reform process justify the assumption that "agenda-crafting" 
mattered and that-in future research-it should indeed be taken into account as a success factor, as Riker (1984) proposes.

\section{Interests and Distributive Bargaining}

The analysis in the preceding sections makes it understandable how distributive interests can be constrained and how "problem-solving" may become a dominant interaction mode in the constitutional arena. However, one should not see the adoption of "problem-solving" during constitutional discussions as a complete switch from one mode of interaction to another. The "bargaining mode" may be in the background, but interests remain in the minds of actors. The "veil of ignorance" helps to raise the level of discussion to "arguing," but it cannot transform selfish interests into common good interests. The constitutional debate remains a "mixed motive game" throughout the whole process. Interests are a permanent latent influence.

During the analysis of the NFA reform, we encountered other facilitating factors that more directly helped to mitigate the intensity of the conflict of interest. As in the case of ideational factors, they can be considered facilitative and substitutable factors of success.

(a) The first facilitating factor is that, from the very start, distributive interests of the federal government and cantons were not strongly polarized. There were "commonalities" that facilitated the search for consensual solutions. The initial bargaining situation at the beginning of the 1970s was the following (Freiburghaus 2001): Two factors played a role in the initial bargaining situation in the early 1970s. One was rising budget deficits that demanded action by the federal government and also by a number of cantons. The other was a process of "creeping centralization" that had taken place after the Second World War. This last development resulted in demands from the more well-to-do cantons to return to the principles laid down in the original constitution in which cantons had obtained a large degree of autonomy and "self-rule." The main interest of the federal government was to spend less money. Decentralization-the demand by richer cantons-was a possible way to achieve this, because it could result in less transfer of subsidies to cantons. Poorer cantons were also in favor of more autonomy and "self-rule," but more important for them was getting more money in order to overcome budget deficits and other financial problems. A reform of competences in favor of more autonomy of cantons was therefore in principle approved by all actors, but the first reform failed to solve the financial conflict between the federal government and poorer cantons, because it did not include a fundamental discussion of equalization payments. This explains why one achieved only a (minor) revision of competences. The NFA reform, by contrast, could succeed, because both 
items (competences and equalization) were linked-in theory and in the legislative proposal. This helped to overcome the fears of poorer cantons of being the losers in constitutional reform, because more responsibilities without increased money would have aggravated their financial problems.

There were therefore common or overlapping interests between actors, above all, with regard to competence distribution. This reduced the intensity of interest conflicts and facilitated the search for a consensus.

(b) In addition to the obvious cleavage between richer and poorer cantons, one finds other differences of interest between cantons: urban cantons and cantons situated in mountain regions had particular problems that had until now been insufficiently taken into account. In short, the task of coming to an agreement with such a large number of actors with dispersed interests was a considerable handicap. The solution, of course, to fragmentation of interests is association, and this was indeed what happened: As early as 1993, cantons decided to bundle their forces by creating the CCG, which was different from the already existing numerous "conferences" of cantonal departments. The CCG became the main coordinating body for the cantons in all matters of NFA reform and more than once served as a platform for reaching a consensus between cantons (Wettstein 2002; Larpin 2006). Without this corporate actor, it might have become very difficult to maintain the "veil of ignorance" for such a long time during constitutional debates. The CCG was crucial in its efforts-together with the coordinating secretariat-to remind cantons of the general interest of the reform and the underlying principles already agreed upon.

(c) The CCG would, of course, not have played this role, if it had not been an equal partner in the reform. Strong inclusion was a necessary condition for the cooperation of the CCG, and such a strong inclusion took place, as indicated earlier: the CCG chose representatives for the committees, nominated representatives for the board of the project group, and participated directly in preparation of the proposals.

(d) The Parliament and party interests were secondary to the interests of the executive. ${ }^{9}$ Since the beginning, the project had been seen as a "territorial matter" that concerned governments and the administration. This allowed not only the pre-structuring of discussions in Parliament but also to avoid a confrontation along the cleavage lines of the party system. Dealing with the fragmented interests of cantons was one thing, but isolating the NFA discussion from the multifarious party interests was another. This does not mean that party interests were discarded altogether. The parties were informed several times when the project group published pre-proposals, opening a way, for example, for the Socialist Party to attack the project, as mentioned earlier. But this was external to negotiations within the "NFA reform system" that tried to arrive at agreements by focusing on 
territorial conflicts and neglecting other interests. Once agreed upon, the "system," that is, all participating actors, could deal "en bloc" with such critical points raised by the Socialist Party and interest groups.

(e) A procedural separation of problem solving and bargaining may be valid until a constitutional amendment has finally been adopted. In the case of the NFA, this was not possible, as a substantial component of the project concerned the distribution of money and the question of who would pay what. At one point, actors had to engage in discussion of distributive consequences. When this is the case, as is well known (Scharpf 1997), compensation payments are needed.

In the beginning, the federal government attempted to limit such payments, but in the long run, it became clear that this attitude could not be maintained. The more wealthy cantons, for example, refused on one occasion to pay their eighty percent share for the "cohesion funds" that they had accepted during the committee debates. They now demanded a reduction of their payments to two-thirds of the sum the federal government was prepared to pay. The compromise stipulated finally that cantons had to pay seventy percent, which in turn meant higher payments by the federal government. Such distributive questions did not jeopardize the general direction of the reform or the consensus on general lines of the project, but they were in conflict with the general objective of efficiency that had been accepted in constitutional debates. It was, however, necessary to satisfy distributive interests in order to make the reform successful. Once a constitutional reform arrives at the distributive level and once the actors are becoming aware of what kind of "pay-offs" can be expected from the reform, pork-barreling, side-payments, and other instruments of the bargaining process are indispensable, and this needs financial room for "side-payments" by the federal government (Zintl 1992).

In sum, this overview demonstrates that diverse interests accompany the process of constitutional negotiation and that, in the case of NFA reform, a number of favorable conditions were present or were realized that helped to mitigate the polarization of interests, which in turn favorably influenced the search for consensus in constitutional debates.

\section{Conclusions}

Our initial question in this article was how could Switzerland-in contrast to Germany and Austria-succeed in fundamentally reforming its federal order? The starting conditions of Switzerland to do so seemed particularly unpromising given its strong inclusion of numerous veto-players in political decision-making and the many veto-points, including referendum. 
An explanation based solely on the "selfish actor" model seemed inadequate to explain the large support among political elites and the people which emerged despite of a fundamental redistribution of competences and revenues that was foreseen in the legislative project.

Alternative explanations were sought by using insights from "constitutional political economy" and "actor-centered institutionalism." These approaches suggest the possibility of a switch in the interaction orientation of actors from bargaining to "problem solving" or "arguing," which allows arriving at an understanding among actors about "joint products" and "common goods." A problem-solving frame of mind, it was stated, seems a necessary condition for achieving a fundamental redistribution of "property rights."

It was therefore asked which causal mechanisms could help to achieve such an interaction mode. The literature offered a number of likely mechanisms and conjectures that were used as an interpretative frame in order to analyze the constitution-making process of the NFA in Switzerland.

Our analysis of the NFA reform process could not prove the explanatory power of this frame or could it test the conjectures in a rigorous way, but the presence of a large number of these conducive factors we found in our quest to understand the NFA reform justifies retaining the interpretative frame for future research.

What mechanisms seemed to matter in the case of the NFA reform?

- A procedural separation of discussions of distributive questions from discussions of general principles in disentangling competences and rebalancing the equalization scheme;

- Active agenda-crafting played a crucial role in achieving such a separation but was also pertinent for dealing with the coherence of the project, for consensusbuilding, and for the search for approval by the people by means of media strategies;

- Ideational factors could be identified and were seen as a favorable influence on the interaction orientation of actors:

- The principle of subsidiarity was reinvigorated in Swiss federal reform processes during the 1990s and could serve as a "focal point," that is as a reassuring mechanism for actors to be protected from future opportunism of other actors;

- "Efficiency" became an omnipresent frame of reference in reform discussions about the NFA. This frame helped to introduce an orientation towards problem-solving and systemic solutions to problems;

- The economic theory of fiscal federalism delivered a coherent "causal theory" about competence distribution and the organization of equalization payments and served as an interpretative frame from the beginning of the reform process. 
- The time dimension mattered: the long-standing reform process occurring in stages allowed the (pre-)structuring of decisions. Agreements reached in a previous stage constrained the choices of actors during later stages of decision. This was important because agreements made in the beginning phase of reforms were still made under the "veil of ignorance." This had positive effects on distributive bargaining later on.

In sum, the procedural separation of decision-making processes, ideational factors, and process variables helped to achieve a problem-solving interaction mode throughout the process of the reform of the NFA. A number of further variables linked to the interests of actors were conducive to mitigating the intensity of the inherent distributive conflict and were therefore helpful for adopting a discussion based on "arguing" instead of "bargaining":

- There were not only differences but also commonalities of interest between the federal government and cantons;

- A fragmentation of cantons could largely be avoided by creating a corporate actor representing cantons in the reform process;

- The cantons were equal partners in the organization of the reform process;

- The reform process was relatively isolated from the party system, reducing the number of possible conflicts of interest;

- Compensation payments became important in the last phase of the negotiation process.

These different elements not only helped in understanding the reform process in Switzerland in a coherent way, but also could be the building blocks of a more general model of constitutional change based on insights from constitutional political economy and actor-centered institutionalism. To this end, one can distinguish between necessary (procedural separation; agenda-crafting) and facilitating, substitutable factors. The arguments used for this distinction were based on various conjectures. Our empirical research could not prove in any way whether procedural separation and agenda-crafting are indeed necessary variables. In order to confirm the conjectures and hypotheses in this study, comparative research is needed comparing constitutional reforms in several countries. Only on the basis of such comparative research could a "causal model" be developed that could then be tested in further studies.

One can, however, ask whether the NFA reform can really be used as an exploratory case that helps to refine a concept of successful constitutional change. It is true that the reform had particularities that should not be forgotten: one is that it was a very encompassing reform that entailed a fundamental redistribution of competences and revenues and, two, it was above all a reform between federal powers, in which party struggle had a minor role. One can also argue that Switzerland has particular cultural and institutional conditions that may have 
favored problem solving, like a political culture of consensus, sophisticated and long-standing processes of decision making, and direct democracy, which usually needs a large consensus among political elites before the people decide. Although these are specific attributes, we do not think that they made the NFA reform unique and incomparable. They should rather be taken into consideration as additional potential explanatory variables that could not be tested by using this case study. In order to know whether the institutional context of Switzerland matters or not, or whether only fundamental redistributive reforms can create conditions for the emergence of the factors highlighted in this study, comparisons are needed.

\section{Notes}

1. Referendum on the "Neugestaltung des Finanzausgleichs und der Aufgabenteilung zwischen Bund und Kantonen" (NFA), November 28, 2004.

2. "Bundesgesetz über die Schaffung und die Änderung von Erlassen zur Neugestaltung des Finanzausgleichs und der Aufgabenteilung zwischen Bund und Kantonen," October 6, 2006.

3. Germany succeeded in 2006 in adopting a small-scale reform in federal competence distribution and is still struggling to revise its fiscal federalism (see Burkhart article in this issue of Publius: The Journal of Federalism). Austria abandoned the reform process after the propositions of a constitutional convent were rejected in Parliament.

4. Veto-players can, if constitutional change is demanded, intervene by using the following veto-points: pre-parliamentary hearings; the oversized coalition government; parliamentary proceedings in two chambers; the referendum in which not only the majority of the people is needed but also the majority of the twenty six cantons.

5. This means that all discussions must have a component of "common good" and that arguments must be presented in an impartial way. This does not mean that selfish arguments are non-existent in the constitutional arena. They may be there and they may partly influence what actors announce but the context of discussion legitimizes above all arguments in favor of the common good.

6. "Agreement seems more likely on general rules for collective choice than on the later choices to be made within the confines of certain agreed-on rules" (Buchanan and Tullock 1962, 77).

7. Most information is based on the following literature: Freiburghaus 1999, 2001; Dafflon 2004; Larpin 2006; Frey et al. 2006; Wettstein 1998, 2002.

8. The final result of the NFA mirrors this general frame in many points. One of the most obvious ones is the new governance mode in concurrent tasks where the federal government now has "steering functions" and transfers global budgets to cantons that have operational freedom to fulfill the tasks agreed upon. An ex-post evaluation takes place. 
9. This becomes clear if one looks at the composition of the two project groups in which only government experts were integrated (Larpin 2006, 61-62).

\section{References}

Blindenbacher, Raoul, Peter Hablützel, and Bruno Letsch, eds. 2000. Vom service public zum service au public. Regierung und verwaltung auf dem weg in die zukunft. Zürich: NZZ Verlag.

Braun, Dietmar, and Andreas Busch, eds. 1999. Public policy and political ideas. Cheltenham: Edward Elgar.

2007. How to make German fiscal federalism self-enforcing: A comparative analysis. Journal for Comparative Government and European Policy 5 (2): 235-62.

Brennan, Geoffrey, and James M. Buchanan. 1985. The reason of rules. Constitutional political economy. Cambridge, MA: Cambridge University Press.

Buchanan, James M. 1987. The constitution of economic policy. American Economic Review 77 (3): 243-50.

Buchanan, James M., and Gordon Tullock. 1962. The calculus of consent. Logical foundations of constitutional democracy. Ann Arbor: University of Michigan Press.

Conférence des Directeurs Cantonaux des Finances. 1992. Orientierungsrahmen für die künftige ausgestaltung des bundesstaatlichen finanzausgleichs. Berne: Conférence des directeurs cantonaux des finances.

Conseil Fédéral. 2001. Message concernant la réforme de la péréquation financière et de la répartition des tâches entre la confédération et les cantons (RPT). Bern: Conseil Fédéral.

Dafflon, Bernard. 2004. Federal-Cantonal equalisation in Switzerland: An overview of the present system and reform in progress. Working Paper No. 356, BENEFRI Centre d'Etudes en Economie du Secteur Publique, Fribourg.

Département Fédéral des Finances. 1996. La nouvelle péréquation financière entre confederation et cantons. Lignes directrices. Bern und Luzern: Rapport de l'organisation de projet instituée conjointement par le Département.

Elster, Jon. 1986. The market and the forum: Three varieties of political theory. In Foundations of social choice theory, ed. Jon Elster, 103-32. Cambridge: Cambridge University Press.

Elster, Jon. 1991. Arguing and bargaining in the federal convention and the assemblée constituante. Working Paper no. 4, Center for the Study of Constitutionalism in Eastern Europe.

Freiburghaus, Dieter. 1999. Aktuelle Entwicklungen im schweizerischen Föderalismus. Working Paper de l'IDHEAP 4/1999, Lausanne: IDHEAP.

Freiburghaus, Dieter. 2001. Aufgabenentflechtung und neuer finanzausgleich zwischen Bund und Kantonen. Zur aktuellen reformdebatte in der Schweiz. Diskussionspapier präsentiert auf der Konferenz: Wandel in föderativen Staaten in Berlin, Juni 8-9, 2001. 
Frey, René L. 2001. Ziel- und Wirkungsanalyse des Neuen Finanzausgleichs. Bericht zu Handen der Eidg. Finanzverwaltung und der Konferenz der Kantonsregierungen, Mai 14, 2001. Bern: OCFIM (Adm. des finances).

Frey, René L., Andreas Spillmann, and Bernard Dafflon. 1994. Péréquation financière entre la confédération et les cantons. Bern: OCFIM (Adm. des finances).

Frey, René L., Georg Kreis, Gian-Reto Plattner, and René Rhinow, eds. 2006. Le fédéralisme suisse. Lausanne: Presses Polytechniques et Universitaires Romandes.

Garrett, Geoffrey, and Barry Weingast. 1993. Ideas, interests, and institutions: Constructing the European community's internal market. In Ideas and foreign policy Beliefs, institutions, and political change, eds. Judith Goldstein, and Robert $\mathrm{O}$ Keohane, Ithaca: Cornell University Press.

Goertz, Gary, and James Mahoney. 2005. Two-level theories and fuzzy-set analysis. Sociological Methods and Research 33 (4): 497-538.

Gygi, Ulrich. 1999. Instrumente und Wirkungen. In Der neue schweizer finanzausgleich. Schriftenreihe der fachgruppe für kantonale finanzfragen, ed. Alfred Rey, Solothurn: Verlag der FkF.

Haas, Peter M. 1992. Introduction: Epistemic communities and international policy coordination. International Organization 46 (1): 1-35.

Immergut, Ellen. 1992. Health politics: Interests and institutions in Western Europe. Cambridge: Cambridge University Press.

Jillson, Calvin C., and Cecil L. Eubanks. 1984. The political structure of constitution making: The federal convention of 1787. American Journal of Political Science 28 (3): 435-458.

Larpin, Blaise. 2006. Réformes contemporaines du fédéralisme: Le cas suisse à la lumière de l'expérience allemande. Lausanne: Institut d'Etudes Politiques et Internationales: University of Lausanne.

Lijphart, Arend. 1999. Patterns of democracy. Government forms and performance in thirty-six countries. Yale University Press: New Haven.

Linder, Wolf. 1994. Swiss democracy Possible solutions to conflict in multicultural societies. MacMillan: Houndsmille: Basingstoke.

Linder, Wolf, Regula Zürcher, and Christian Bolliger. 2008. Gespaltene Schweiz-Geeinte Schweiz. Gesellschaftliche Spaltungen und Konkordanz bei den Volksabstimmungen seit 1874, hier + jetzt. Verlag für Kultur und Geschichte: Baden.

Lindenberg, Siegwart. 2000. The extension of rationality: Framing versus cognitive rationality. In L'acteur et ses raisons Mélanges en l'honneur de Raymond Boudon, eds. Jean Baechler, François Chazel, and Ramine Kamrane, 168-204. Paris: Presses Universitaires de France.

Neidhart, Leonhard. 2002. Die politische schweiz. Fundamente und institutionen. Verlag Neue Zürcher Zeitung: Zürich.

Oates, Wallace E. 1972. Fiscal federalism. New York: Harcourt Brace Jovanovich. 
Olson, Mancur. 1969. The principle of "fiscal equivalence": The division of responsibilities among different levels of government. American Economic Review 59: 479-487.

Rawls, John. 1999. A theory of justice. Oxford: Oxford University Press.

Rein, Martin, and Donald Schön. 1993. Reframing policy discourse. In The argumentative turn in policy analysis and planning, eds. Frank Fischer and John Forester, 145-66. London: Duke University Press.

Rey, Alfred. 1994. Finanzföderalismus zwischen Bund, Kantonen und Gemeinden. In Finanzföderalismus, eds. Franz Eng, Alexander Glatthard, and Beat H. Koenig, 12-29. Bern: Emissionszentrale der Schweizer Gemeinden.

Rieder, Stefan, and Luzia Lehmann. 2002. Evaluation of new public management reforms in Switzerland: Empirical results and reflections on methodology. International Public Management Review 3 (2): 25-43.

Riker, William H. 1984. The heresthetics of constitution-making: The presidency in 1787, with comments on determinism and rational choice. The American Political Science Review 78 (1): 1-16.

Scharpf, Fritz W. 1988. The joint-decision trap: Lessons from German federalism and European integration. Public Administration 66 (3): 239-78.

- 1997. Games real actors play: Actor-centered institutionalism in policy research. Boulder, CO: Westview Press.

Schelling, T. C. 1978. Micromotives and macrobehavior. New York: W.W. Norton.

Schmidt, Vivien A. 2008. Discursive institutionalism: The explanatory power of ideas and discourse. Annual Review of Political Science 11: 303-26.

Sciarini, Pascal. 2004. The decision-making process. In Handbook of Swiss politics, eds. Ulrich Klöti et al., 509-62. Zürich: Verlag Neue Zürcher Zeitung.

Siegenthaler, Peter, and Gérard Wettstein. 2004. Die interkantonale zusammenarbeit im rahmen der neugestaltung des finanzausgleichs und der aufgabenteilung zwischen bund und kantonen (NFA). In Perspektiven der wirtschaftspolitik. Festschrift zum 65. Geburtstag von Prof. Dr. René L. Frey, eds. Christoph A. Schaltegger, and Stefan C. Schaltegger, 87-106. Zürich: vdf Hochschulverlag.

Tiebout, Charles M. 1956. A pure theory of local expenditures. Journal of Political Economy 64 (5): 416-24.

Tsebelis, George. 2002. Veto players. How political institutions work. Princeton: Russel Sage Foundation/Princeton University Press.

Tversky, Amos, and Daniel Kahneman. 1974. Judgment under uncertainty: Heuristics and bias. Science 185 (4157): 1124-31.

Vanberg, Viktor, and James M. Buchanan. 1989. Interests and theories in constitutional choice. Journal of Theoretical Politics 1 (1): 49-62.

Weingast, Barry R. 1995. A rational choice perspective on the role of ideas: Shared belief systems and state sovereignty in international cooperation. Politics \& Society 23 (4): 449-64. 
Wettstein, Gérard 2002. Die neugestaltung des finanzausgleichs und der aufgaben (NFA) Erfolgsfaktoren und hürden aus sicht der projektleitung. Leges 2: 35-54.

. 1998. La nouvelle péréquation entre la confédération et les cantons. Revue de Politique Économique 0: 58-62.

Zintl, Reinhard. 1992. Kooperation und aufteilung des kooperationsgewinns bei horizontaler politikverflechtung. In Horizontale politikverflechtung. Zur theorie von verhandlungssystemen, eds. Arthur Benz, Fritz W. Scharpf, and Reinhard Zintl, 97-146. Campus: Frankfurt a.M. 